\title{
Does "IT Doesn't Matter" Matter?: A Study Of Innovation And Information Systems Issues
}

Arthur H. Gilbert, Jr., Northeastern State University, USA Roger Alan Pick, University of Missouri-Kansas City, USA Sidne Gail Ward, University of Missouri-Kansas City, USA

\begin{abstract}
A new analysis of secondary data examines Carr's controversial Harvard Business Review article of 2003 by considering the relative importance of top information systems issues according to the level of innovation in an industry. Although the majority of the subsequent literature argues that Carr was wrong, our analysis provides evidence suggesting that Carr may have been right.
\end{abstract}

Keywords: Information Systems Issues; Information Technology Innovation

\section{INTRODUCTION}<smiles>[C]1C=CCCC1</smiles>
ince its appearance in the Harvard Business Review, "IT Doesn't Matter" (Carr, 2003) has been a subject of controversy. While the title is provocative, the article is subtler and more nuanced than its title suggests. The essence of Carr's argument is that information technology (IT) is less of a strategic differentiator among firms than it once was. Instead, its ubiquity makes it, in effect, an equalizer - the same technology is available for purchase to everyone. He suggests that rather than seeking advantage, companies should instead manage to reduce costs and risks. Carr's article was later expanded into a similarly controversial book (Carr, 2004).

After the appearance of the 2003 article, a number of letters appeared in Harvard Business Review print edition and more on the website (Brown \& Habel, III, 2003; Varian, 2003; Hittleman, 2003; McFarlan \& Nolan, 2003; Strassmann, 2003; Broadbent, McDonald, \& Hunter, 2003; Skaistis, 2003; Zwass, 2003; Lewis, 2003; Pisello, 2003; Pike, 2003; Gurbaxani, 2003; Alter, 2003; Hyatt, 2003; and Langdon, 2003). Many of the writers agreed with portions of Carr's argument, but generally found his conclusions overbroad and overgeneralized. For example, Brown \& Habel, III (2003) note that Carr's main assertion is that "IT is diminishing as a source of strategic differentiation" and they worry that "many readers will remember the article's title and forget its nuance." Their concern about the title of the article is a common complaint among authors of these letters.

Some authors contend that strategic differentiation does not come from software, but instead from the ability to recruit an IT staff, to execute well, and to possess good business process knowledge. An example of this assertion comes from Varian (2003), "Knowing how to use IT effectively is still a relatively scarce skill." Similarly, Broadbent, McDonald, \& Hunter (2003) say that the differentiation is not about hardware and software, but instead, about "information, business processes, and applications". Pisello (2003) writes, "Commoditization of technologies does not translate into making the best IT implementations easily replicable." Gurbaxani (2003) says, "The scarce resource never was technology ... it was always the set of managerial capabilities needed to create value with that technology."

Others argue that innovations continue to emerge. For example, McFarlan \& Nolan (2003) contend that rapid adoption of new innovations conveys an advantage; "The first mover takes a risk and gains a temporary advantage ... The fast follower is up against less risk but also has to recover lost ground." Zwass (2003) notes the 
ironic contradiction that two other articles in the same issue of Harvard Business Review are about strategic impacts of IT upon two individual firms. Pike (2003) notes that strategic use of IT has moved from internal improvements and goes on to say, "By linking business processes, IT is and will remain of strategic importance for the next ten years." Langdon (2003) notes that information systems vary in their versatility and "value added is constantly being shifted into or embedded in software, with mature areas obviously becoming commoditized.... Why would this process stop? Why would there suddenly be only mature areas?"

Several authors rightly object to Carr's methodology, particularly his use of analogy as a replacement for proof. For example, Hyatt (2003), Strassmann (2003), and Lewis (2003) protest the use of analogies as a device for reasoning and proof. Alter (2003) goes so far as to mock Carr with his own analogy about kidneys. The problem with analogy is that there is no reason to infer something from it. Carr correctly notes that there are similarities between information technology today with electricity and railroads at a certain point in their development. Those similarities do not, in any way, prove that information technology today is similar to electricity nor to railroads in all respects.

However, a couple of letter-writers accept the broad thrust of Carr's conclusions. Hittleman (2003) accepts that IT is becoming a commodity but argues that IT management remains "challenging and rewarding." Skaistis (2003) accepts that investing in IT to achieve lasting strategic advantage is unrealistic, but he suggests that properly targeted efforts will matter.

The controversy spilled beyond the pages of the Harvard Business Review with many responses on either websites or trade publications (Bartholomew, 2003; Champy, 2003; Evans, 2003; Ferranti, 2004; Hayes, 2003; Johnson, 2004; Kirkpatrick, 2003; Melymuka, 2003; Metcalf, 2004; Mollenhauer, 2003; Moschella, 2003; and Rothke, 2004).

\section{CONTINUING THE CONTROVERSY}

Our own disagreement with Carr is over three issues. First, we disagree with Carr's assertion that IT innovations are equally available to all. It is our position that some information technologies are mature and widely available, yet others are not. As today's innovative information technologies become mature, new and inventive information technologies will become available. Second, the ability to execute well is not ubiquitous. Two different firms applying the same technology will achieve different levels of success. We believe that this discrepancy is due to differing abilities to execute. Third, Carr's methodology of arguing his case using analogies between IT and older technologies, such as rail transport and electricity, is flawed. Although analogy is a useful communication tool and can convey insights, analogy is not proof. We argue that there are more differences between IT and electricity than similarities.

Carr himself argues that his thesis has become true only recently and that IT was, at one time, a differentiator. "When the locus of technological innovation shifts from users to vendors, as it has with software, it becomes ever harder for companies to distinguish themselves." (Carr 2004, page 48) We will discuss these three areas of disagreement and then focus upon innovation for the remainder of this paper.

\section{Innovation}

Our first disagreement with Carr is about the status of IT innovation. Information technology innovation has not ceased, but rather remains vibrant and fluid with the passage of time. IT enables organizations to be more agile than they could be otherwise (Lee, 2012). There are several technologies that are becoming mainstream today that either did not exist or were highly immature when Carr's article was written. Examples include smart phones, 3D printers, mobile-commerce, social media, phone apps, tablet computing, business analytics, big data, locationbased services, radio frequency identification tags (Jaska, Johnson, Nalla, Reddy, \& Tadisina, 2010), the Internet of Things, and cloud-based computing. Corporate IT departments today are struggling with choosing which of these technologies to adopt and how to adopt them both effectively and efficiently (Giles, 2011; Hinchcliffe, 2011). Using the smart phone example, a company is challenged to choose a replacement for Blackberries for employees. The company must choose between using both Android and iPhones or using just one form. Additionally, the 
company must decide how to transition from the use of Blackberries to the new wireless device. Furthermore, in an interview in Hopkins (2010), Brynjolfsson argues that information technology is "the most important driver of innovation" in our times. Even though innovative information technologies may be available for purchase, how to use them for business advantage is generally not well-understood. According to Cash, Earl, \& Morison (2008), "Companies rely on IT as a catalyst, enabler, and component of the new products, services, channels, processes, and business models, as well as the way to encourage innovators to collaborate." In interviews with 24 chief information officers (CIOs), Cash, Earl, \& Morison (2008) go on to note that a third of the CIOs were "focused on their corporations' innovation ... initiatives."

\section{Execution}

Our second disagreement with Carr concerns execution since the ability to execute well is not ubiquitous. Although Commercial Off The Shelf (COTS) software might be the same from one firm to another, the ability to configure, convert to, and operate that software varies - sometimes by a great deal. Some companies, such as Cisco and Tektronix, have successfully implemented COTS Enterprise Resource Planning (ERP) software, but that expertise is not everywhere. Well-known failures in ERP implementations, such as Hershey (Stedman, 2000b), Grainger (Stedman, 2000a), FoxMeyer (Bulkeley, 1996; Scott, 1999), Whirlpool, Cleveland State University (Carnevale, 2004), and others not yet well-known, such as Major Brands (Kanaracus, 2011), illustrate that the expertise to implement COTS ERP software is not ubiquitous. In a later writing, Carr (2004) agrees, to some extent, with this point, saying "The companies that succeed ... [will be] those that are pragmatic in planning and competent in execution," (page 112). Carr's statement is in the context of an argument to innovate conservatively.

\section{Analogies}

Our final disagreement with Carr concerns the use of analogies in his arguments. Analogy is not proof. Although analogy is a powerful explanatory tool, the fact that two phenomena have some similarities does not imply that they are similar in all ways. For example, we often use temperature as an analogy to how well people get along. An interpersonal relationship might be cold, cool, warm, or hot, but people will never get frostbite from being enemies. The use of the electricity analogy in Carr's article causes the article to provide misleading conclusions to the reader. Electricity is a simple product that can be completely described with a small number of metrics, including wattage, amperage, and voltage. In contrast, the number of metrics required to describe all the possible features of COTS is too vast to list. There is no end to the number of ways in which electricity differs from software, even if we restrict the discussion to COTS and do not consider custom-developed software. Carr's article also lists similarities between railroads and information technology. We accept a few similarities but argue that the list of differences is far longer.

\section{The Importance of IT}

Carr's article has received such vast attention because it causes us to reconsider the importance of information technology at all levels of the firm. In particular, it forces us to reconsider the level of attention information technology needs to receive from top management. The focus of the present article will be to examine Carr's article in the context of innovation within the firm.

In the last 50 years, software repeatedly has been a source of innovation within the firm. From accounting and payroll to social networking and mobile payments, software has changed the way firms do business. Carr's argument is that IT, in general, (including software) is no longer a source of innovation and therefore has ceased to matter. We believe that if IT does not matter, then firms in innovative industries would not have a drastically different view of information systems than firms in staid industries. We have already conducted a series of studies of information systems issues (Gilbert, Jr., Pick, \& Ward, 2003; Gilbert, Jr., Pick, \& Ward, 1999). Our studies have led us to believe that if IT matters and IT matters for reasons of innovation, then innovative firms will have significantly different views of IT issues than less innovative firms. We furthermore expect that since IT is a source of business innovation (Brynjolfsson \& Saunders, 2010; Lin, 2011), IT issues will be more important at firms in innovative industries. 


\section{MODEL}

The model is based on the hypothesis that CIOs of firms in innovative industries view the importance of information systems (IS) issues differently than CIOs in less innovative industries. Specifically, we hypothesize that information systems are more important at firms in innovative industries, such as software or biotech, than at firms in less innovative industries, such as daily newspapers. We hold this statement to be true because we believe that information systems are a major driver of innovation. Because information systems are important in innovative industries, our respondents from those industries will consider information systems issues to be more important than our respondents from less innovative industries. These ideas are expressed in Figure 1 and in the following hypotheses.

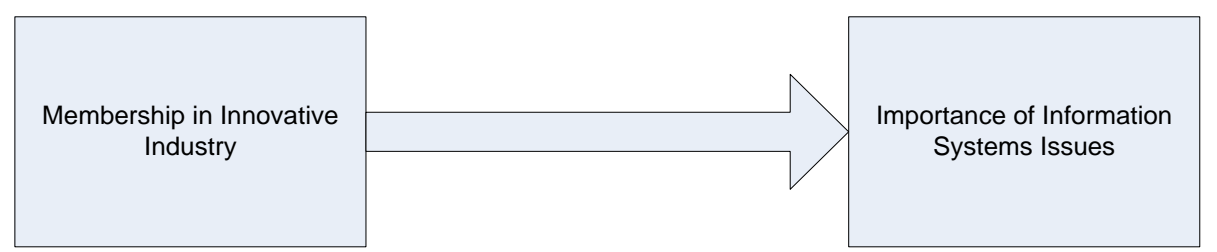

Figure 1: Information Systems Issues are More Important at Firms Which Operate in Innovative Industries

H1: CIOs at firms which operate in high innovation industries will attach more importance to information systems issues than CIOs at firms which operate in medium innovation industries.

H2: CIOs at firms which operate in high innovation industries will attach more importance to information systems issues than CIOs at firms which operate in low innovation industries.

H3: CIOs at firms which operate in medium innovation industries will attach more importance to information systems issues than CIOs at firms which operate in low innovation industries.

\section{DATA COLLECTION}

The present study is an analysis of secondary data. This data were collected by the authors for earlier studies of information systems issues. In order to focus upon issues that have staying power, we chose issues that have appeared in at least three out of five major studies of information systems issues (Ball \& Harris, 1982; Dickson, Leitheiser, \& Nechis, 1984; Brancheau \& Wetherbe, 1987; Niederman, Brancheau, \& Wetherbe, 1991; Brancheau, Janz, \& Wetherbe, 1996). From these studies, a questionnaire was constructed to collect demographic information about the responder and firm in addition to Likert scales rating the importance of each issue from 1 (Not Important) to 7 (Extremely Important). The list of issues is found in Table 1. The questionnaire was sent to the CEO of a sample of 1948 publicly-traded firms found in the Compact Disclosure database. In order to simplify analysis of firms' relative financial performance, the sample consisted only of firms in Compact Disclosure doing business in a single Standard Industrial Classification (SIC) code. This decision, made years ago, had a fortuitous effect upon the present study by making it possible to classify each firm's level of innovation according to the level of innovation in its industry. The CEO was asked to forward the survey to the CIO, defined operationally as the person most familiar with the firm's information technology. The data were collected in preparation for Gilbert, Jr., Pick, \& Ward (2003) and was supplemented for this study with data from Kirchoff (1994). 
Table 1: Information Technology Issues

\begin{tabular}{ll}
\hline \multicolumn{1}{c}{ Brief Name } & \multicolumn{1}{c}{ Full Text of Item } \\
\hline Strategic Planning & Improving information systems strategic planning. \\
End User Computing & Facilitating and managing end-user computing. \\
Software Development & Improving the effectiveness of software development. \\
IS Effectiveness \& Productivity & Measuring information systems effectiveness and productivity. \\
Organizational Learning & Facilitating organizational learning and the use of information systems. \\
Aligning IS Organization with Enterprise & Aligning the information systems organization with that of the enterprise. \\
IS Human Resources & Specifying, recruiting, and developing information systems human resources. \\
Data Resources & Promoting effective use of the data resource. \\
Applications Portfolio & Planning and managing the applications portfolio. \\
Telecommunications & Planning, implementing, and managing telecommunications. \\
Role \& Contribution of IS & Increased understanding of the roles and contributions of information systems. \\
Competitive Advantage & Using information systems for competitive advantage. \\
Mulitvendor Integration & Enabling electronic data interchange and multi-vendor integration. \\
Security and Control & Improving information security and control. \\
Information Architecture & Developing an information architecture. \\
\hline
\end{tabular}

\section{ANALYSIS}

A total of 104 usable responses came from companies operating in the SIC codes shown in Table 2. The mean count of information technology sites at the responding companies was 71.9 with an average information technology organization staff of 153.8. The responding companies represented 92 different SIC codes and all companies in the sample limited their operations to a single SIC. Also, not a single one of the responding companies is a software or other type of IT company. It would be accurate to say that the respondents consist entirely of representatives of IT-using companies without a single IT-producing company.

Table 2: Distribution of Respondents by Two-digit SIC Code

\begin{tabular}{|c|c|c|}
\hline SIC Code & Description & Responses \\
\hline 10 & Metal Mining & 1 \\
\hline 13 & Oil \& Gas Extraction & 6 \\
\hline 22 & Textile Mill Products & 1 \\
\hline 26 & Paper \& Allied Products & 1 \\
\hline 27 & Printing \& Publishing & 2 \\
\hline 28 & Chemicals \& Allied Products & 5 \\
\hline 30 & Rubber \& Misc Plastic Products & 1 \\
\hline 31 & Leather \& Leather Products & 1 \\
\hline 32 & Stone, Clay, \& Glass Products & 1 \\
\hline 33 & Primary Metal Industries & 3 \\
\hline 35 & Industrial Machinery \& Equipment & 6 \\
\hline 36 & Electronic \& Other Electric Equipment & 4 \\
\hline 38 & Instruments \& Related Equipment & 8 \\
\hline 39 & Misc Manufacturing Industries & 1 \\
\hline 45 & Transportation by Air & 1 \\
\hline 47 & Transportation Services & 1 \\
\hline 48 & Communications & 3 \\
\hline 49 & Electric, Gas, \& Sanitary Services & 13 \\
\hline 50 & Wholesale Trade-Durable Goods & 1 \\
\hline 52 & Building Materials \& Garden Supplies & 1 \\
\hline 53 & General Merchandise Stores & 1 \\
\hline 56 & Apparel \& Accessory Stores & 1 \\
\hline 57 & Furnishings \& Home Furnishing Stores & 1 \\
\hline 58 & Eating \& Drinking Establishments & 3 \\
\hline 59 & Miscellaneous Retail & 4 \\
\hline 60 & Depository Institutions & 5 \\
\hline 61 & Nondepository Institutions & 4 \\
\hline 62 & Security \& Commodity Brokers & 1 \\
\hline 63 & Insurance Carriers & 4 \\
\hline
\end{tabular}


Real Estate

Hotel \& Other Lodging Places

Personal Services

Business Services

Amusement \& Recreation Services

Health Services

Social Services

Engineering \& Management Services

Total

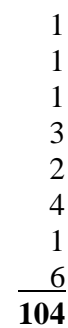

The low response rate is a concern insofar as respondents might be different from nonrespondents. We tested to see if there were any systematic differences between the first quartile of responders and the last quartile of responders with the last quartile being considered a proxy for nonresponders. Since we did not find any significant differences, we follow Churchill's (1991) suggestion that the low response rate does not add any significant biases to the analysis of the data.

We divided firms by SIC code according to industries classified by Kirchoff (1994) as being highinnovation or low-innovation. Industries not classified by Kirchoff were treated as being medium-innovation. Using this classification, 17 of the firms in the sample were high-innovation firms, 76 were medium-innovation firms, and 11 of the firms were low-innovation. Table 3 shows the mean importance of each issue among the firms in high-innovation industries, in medium-innovation industries, and in low-innovation industries. An examination of Table 3 shows a strong overall pattern whereby nearly every issue is more important at medium-innovation industries than at high-innovation industries and also more important at low-innovation industries than at mediuminnovation industries. Most of these differences are not highly significant, but the overall pattern suggests that Carr had a point in spite of all the arguments against him.

Table 3: Comparison of the Importance Ranking of Issues CIOs from High, Medium, and Low Innovation Industries

\begin{tabular}{|c|c|c|c|c|c|c|}
\hline \multirow[b]{2}{*}{ Issue } & \multicolumn{2}{|c|}{$\begin{array}{l}\text { High Innovation } \\
\text { Industries }\end{array}$} & \multicolumn{2}{|c|}{$\begin{array}{l}\text { Medium Innovation } \\
\text { Industries }\end{array}$} & \multicolumn{2}{|c|}{$\begin{array}{l}\text { Low Innovation } \\
\text { Industries }\end{array}$} \\
\hline & Rank & Mean & Rank & Mean & Rank & Mean \\
\hline $\begin{array}{l}\text { Aligning the Information Systems Organization } \\
\text { with that of the Enterprise }\end{array}$ & $1 *$ & 4.88 & 1 & 5.95 & $12 *$ & 5.09 \\
\hline Developing an Information Architecture & $1^{*}$ & 4.88 & 6 & 5.35 & $5^{*}$ & 5.55 \\
\hline Promoting Effective Use of the Data Resource & 3 & 4.82 & 4 & 5.49 & 3 & 5.73 \\
\hline $\begin{array}{l}\text { Increased Understanding of the Roles and } \\
\text { Contributions of Information Systems }\end{array}$ & 4 & 4.71 & 11 & 5.05 & 8 & 5.36 \\
\hline Facilitating and using End-User Computing & 5 & 4.65 & 3 & 5.64 & $5 *$ & 5.55 \\
\hline $\begin{array}{l}\text { Using Information Systems for Competitive } \\
\text { Advantage }\end{array}$ & $6^{*}$ & 4.59 & 2 & 5.71 & 2 & 5.82 \\
\hline $\begin{array}{l}\text { Improving Information Systems Strategic } \\
\text { Planning }\end{array}$ & $6^{*}$ & 4.59 & 5 & 5.46 & 11 & 5.18 \\
\hline $\begin{array}{l}\text { Facilitating Organizational Learning and the } \\
\text { Use of Information Systems }\end{array}$ & 8 & 4.47 & 7 & 5.30 & 4 & 5.64 \\
\hline Improving Information Security and Control & 9 & 4.24 & 13 & 4.84 & $9 *$ & 5.27 \\
\hline $\begin{array}{l}\text { Measuring Information Systems Effectiveness } \\
\text { and Productivity }\end{array}$ & 10 & 4.06 & 9 & 5.17 & $9 *$ & 5.27 \\
\hline $\begin{array}{l}\text { Planning, Implementing, and Managing } \\
\text { Telecommunications }\end{array}$ & 11 & 4.00 & 8 & 5.25 & $12 *$ & 5.09 \\
\hline $\begin{array}{l}\text { Specifying, Recruiting, and Developing } \\
\text { Information Systems Human Resources }\end{array}$ & 12 & 3.65 & 15 & 4.68 & 15 & 3.91 \\
\hline $\begin{array}{l}\text { Improving the Effectiveness of Software } \\
\text { Development }\end{array}$ & $13 *$ & 3.59 & 10 & 5.09 & 1 & 5.91 \\
\hline $\begin{array}{l}\text { Planning and Managing the Applications } \\
\text { Portfolio }\end{array}$ & $13 *$ & 3.59 & 12 & 5.01 & 7 & 5.45 \\
\hline Enabling EDI and Multi-Vendor Integration & 15 & 3.53 & 14 & 4.79 & 14 & 4.82 \\
\hline
\end{tabular}

*Tie within a column 
Because of the large number of tests, a straight t-test for each issue would likely produce at least one spurious significant result. We need to adjust the p-values for multiple comparisons. A straightforward Bonferroni adjustment proved to be too conservative. Instead, we used a bootstrap resampling adjustment to p-values as implemented by the SAS MULTTEST procedure. Results are shown in Table 4. Most of the differences are not significant, but there are two exceptions as we will discuss below. As mentioned above, these differences are in the opposite direction from what we expected.

Table 4: T-Tests Comparing of the Importance Ranking of Issues CIOs from High, Medium, and Low Innovation Industries

\begin{tabular}{|c|c|c|c|c|}
\hline Issue & $\begin{array}{c}\text { Innovation } \\
\text { Level }\end{array}$ & Mean & $\begin{array}{l}\text { Standard } \\
\text { Deviation }\end{array}$ & $\begin{array}{l}\text { Bootstrap } \\
\text { P-Value }\end{array}$ \\
\hline $\begin{array}{l}\text { Aligning the Information Systems Organization with that } \\
\text { of the Enterprise }\end{array}$ & $\begin{array}{c}\text { High } \\
\text { Medium } \\
\text { Low }\end{array}$ & $\begin{array}{l}4.88 \\
5.95 \\
5.09\end{array}$ & $\begin{array}{l}1.73 \\
1.09 \\
1.81 \\
\end{array}$ & 1.00 \\
\hline Developing an Information Architecture & $\begin{array}{c}\text { High } \\
\text { Medium } \\
\text { Low }\end{array}$ & $\begin{array}{l}4.88 \\
5.35 \\
5.55\end{array}$ & $\begin{array}{l}1.96 \\
1.24 \\
1.21\end{array}$ & 0.89 \\
\hline Promoting Effective Use of the Data Resource & $\begin{array}{c}\text { High } \\
\text { Medium } \\
\text { Low }\end{array}$ & $\begin{array}{l}4.82 \\
5.49 \\
5.73 \\
\end{array}$ & $\begin{array}{l}1.74 \\
1.03 \\
1.10 \\
\end{array}$ & 0.37 \\
\hline $\begin{array}{l}\text { Increased Understanding of the Roles and Contributions of } \\
\text { Information Systems }\end{array}$ & $\begin{array}{c}\text { High } \\
\text { Medium } \\
\text { Low }\end{array}$ & $\begin{array}{l}4.71 \\
5.05 \\
5.36\end{array}$ & $\begin{array}{l}1.57 \\
1.35 \\
1.96\end{array}$ & 0.92 \\
\hline Facilitating and using End-User Computing & $\begin{array}{c}\text { High } \\
\text { Medium } \\
\text { Low }\end{array}$ & $\begin{array}{l}4.65 \\
5.64 \\
5.55 \\
\end{array}$ & $\begin{array}{l}1.87 \\
1.00 \\
1.04 \\
\end{array}$ & 0.39 \\
\hline Using Information Systems for Competitive Advantage & $\begin{array}{c}\text { High } \\
\text { Medium } \\
\text { Low }\end{array}$ & $\begin{array}{l}4.59 \\
5.71 \\
5.82\end{array}$ & $\begin{array}{l}2.00 \\
1.59 \\
1.89 \\
\end{array}$ & 0.45 \\
\hline Improving Information Systems Strategic Planning & $\begin{array}{c}\text { High } \\
\text { Medium } \\
\text { Low }\end{array}$ & $\begin{array}{l}4.59 \\
5.46 \\
5.18\end{array}$ & $\begin{array}{l}2.21 \\
1.22 \\
1.72\end{array}$ & 0.97 \\
\hline $\begin{array}{l}\text { Facilitating Organizational Learning and the Use of } \\
\text { Information Systems }\end{array}$ & $\begin{array}{l}\text { High } \\
\text { Medium } \\
\text { Low }\end{array}$ & $\begin{array}{l}4.47 \\
5.30 \\
5.64\end{array}$ & $\begin{array}{l}1.46 \\
1.19 \\
1.43\end{array}$ & 0.18 \\
\hline Improving Information Security and Control & $\begin{array}{c}\text { High } \\
\text { Medium } \\
\text { Low }\end{array}$ & $\begin{array}{l}4.24 \\
4.84 \\
5.27 \\
\end{array}$ & $\begin{array}{l}1.64 \\
1.43 \\
1.27 \\
\end{array}$ & 0.47 \\
\hline $\begin{array}{l}\text { Measuring Information Systems Effectiveness and } \\
\text { Productivity }\end{array}$ & $\begin{array}{c}\text { High } \\
\text { Medium } \\
\text { Low }\end{array}$ & $\begin{array}{l}4.06 \\
5.17 \\
5.27 \\
\end{array}$ & $\begin{array}{l}1.92 \\
1.19 \\
1.35 \\
\end{array}$ & 0.20 \\
\hline $\begin{array}{l}\text { Planning, Implementing, and Managing } \\
\text { Telecommunications }\end{array}$ & $\begin{array}{l}\text { High } \\
\text { Medium } \\
\text { Low }\end{array}$ & $\begin{array}{l}4.00 \\
5.25 \\
5.09\end{array}$ & $\begin{array}{l}1.77 \\
1.52 \\
2.21\end{array}$ & 0.56 \\
\hline $\begin{array}{l}\text { Specifying, Recruiting, and Developing Information } \\
\text { Systems Human Resources }\end{array}$ & $\begin{array}{c}\text { High } \\
\text { Medium } \\
\text { Low }\end{array}$ & $\begin{array}{l}3.65 \\
4.68 \\
3.91\end{array}$ & $\begin{array}{l}2.23 \\
1.69 \\
1.76\end{array}$ & 1.00 \\
\hline Improving the Effectiveness of Software Development & $\begin{array}{l}\text { High } \\
\text { Medium } \\
\text { Low }\end{array}$ & $\begin{array}{l}3.59 \\
5.09 \\
5.91\end{array}$ & $\begin{array}{l}2.00 \\
1.65 \\
1.04\end{array}$ & $0.006^{*}$ \\
\hline Planning and Managing the Applications Portfolio & $\begin{array}{l}\text { High } \\
\text { Medium } \\
\text { Low }\end{array}$ & $\begin{array}{l}3.59 \\
5.01 \\
5.45 \\
\end{array}$ & $\begin{array}{l}1.97 \\
1.30 \\
1.21 \\
\end{array}$ & $0.012 *$ \\
\hline Enabling EDI and Multi-Vendor Integration & $\begin{array}{l}\text { High } \\
\text { Medium } \\
\text { Low }\end{array}$ & $\begin{array}{l}3.53 \\
4.77 \\
4.82\end{array}$ & $\begin{array}{l}2.15 \\
1.71 \\
2.18\end{array}$ & 0.49 \\
\hline
\end{tabular}


As Table 4 shows, two issues were significant. The first was "Improving the effectiveness of software development" with mean importance of 3.59 for high-innovation firms, mean importance of 5.09 for mediuminnovation firms, and mean importance of 5.91 for low-innovation firms. This issue was more important at firms in less-innovative industries with a p-value of .006 . The second significant issue was "Planning and managing the applications portfolio" with mean importance of 3.59 for high-innovation firms, mean importance of 5.01 for medium-innovation firms, and mean importance of 5.45 for low-innovation firms. This issue was more important at firms in less-innovative industries with a p-value of .012. In the factor analysis in Gilbert, Jr., Pick, \& Ward (1999), both of these issues loaded to a single factor labeled SOFTWARE.

Both issues where there are significant differences are related to software. Since developing custom software is where one would be likely to see innovative use of information technology, we would find this significance supportive of our contention, except that the direction is exactly wrong. Both of these issues are less important at the firms in more innovative industries.

However, there is a pattern throughout the results that is suggestive, even if not significant. In every case, these issues are more important at low-innovation industries and less important at high-innovation industries. This is just the opposite of the result we were looking for and seems to support Carr's ideas. Firms in high-innovation industries find all of these issues less important than firms in low-innovation industries. This suggests to us that the innovative industries are doing their innovations in areas other than information technology. This seems to support Carr's ideas.

\section{CONCLUSION}

Much to our surprise, this new analysis of our data supports Carr's argument. Remember, too, that Carr argued that the commoditization of IT was a relatively new phenomenon in 2003. The age of our data shows that a change in the organizational impact of IT may have occurred sooner than Carr's first article delineating his ideas. Our results are not a total surprise. For example, Wang (2010) found that following fashions in information technology did not result in higher performance. Melville \& Ramirez (2007) have found that innovations are influenced by information processing requirements.

This conclusion may be an artifact of our sample. None of the firms in the data set were operating in information technology-producing industries. Instead, they are all from information technology-using industries. The fact that all the firms in our data set are IT-using firms suggests that the innovation is not in the execution of IT, but perhaps in information technology-producing firms. That will be a matter for future study.

The lesson from this study for practitioners, at least those at information technology-using industries, is to manage information technology to keep costs and risks under control and look elsewhere for innovation.

\section{AUTHOR INFORMATION}

Arthur H. Gilbert, Jr. is Professor of Accounting and William F. Tolbert Endowed Chair in Business at Northeastern State University. He holds a D.B.A. in Accounting from Louisiana Tech University. His research interests are in the relationships among information systems design and environmental variables affecting organizations and performance. His research has been published in Advances in Accounting Information Systems, Journal of Computer Information Systems, Journal of Applied Business Research, Review of Business Information Systems, Industrial Management and Data Systems, and other outlets. Contact: 918-449-6505, Department of Accounting and Finance, College of Business and Technology, Northeastern State University, BABT 124B, 3100 East New Orleans Street, Broken Arrow, OK 74014. E-mail: gilber12@nsuok.edu

Roger Alan Pick is Professor of Management Information Systems at the Henry W. Bloch School of Management at the University of Missouri - Kansas City. He earned a Ph.D. from the Krannert Graduate School of Management at Purdue University in 1984. Pick's research interests are in decision support systems and management of information technology. His research on these topics has appeared in Communications of the ACM, Management Science, Journal of MIS, Decision Support Systems, IEEE Transactions, Information and Management, and 
numerous other outlets. These papers have been cited more than 200 times. Contact: 816-235-2336, Henry W. Bloch School of Management, University of Missouri - Kansas City, 5110 Cherry Street, Kansas City, MO 641102499. E-mail: pickr@umkc.edu (Corresponding author)

Sidne G. Ward is Associate Professor of Management Information Systems at the Henry W. Bloch School of Management at UMKC. Ward received a B.A. in Russian Language and Literature and an M.B.A. from the University of Oklahoma. She holds a Ph.D. in Management from the Anderson School at the University of California, Los Angeles. Ward's current research interests include browser and other information system user interfaces, cognitive biases, decision making and decision support systems, online auctions and electronic commerce, and information systems issues. Contact: 816-235-2321, Henry W. Bloch School of Management, University of Missouri - Kansas City, 5110 Cherry Street, Kansas City, MO 64110-2499. E-mail: wards@umkc.edu

\section{REFERENCES}

1. $\quad$ Alter, S. (2003). Letters to the Editor. Harvard Business Review.

2. $\quad$ Ball, L., \& Harris, R. (1982). SMIS Members: A Membership Analysis. MIS Quarterly, 6(1), 19-38.

3. Bartholomew, D. (2003, September). Yes, Nicholas, IT does matter. Industry Week, 44.

4. Brancheau, J. C., \& Wetherbe, J. C. (1987, March). Key Issues in Information Systems Management. MIS Quarterly, 11(1), 23-45.

5. Brancheau, J. C., Janz, B. D., \& Wetherbe, J. C. (1996, June). Key Issues in Information Systems Management: 1994-95 SIM Delphi Results. MIS Quarterly, 20(2), 225-242.

6. Broadbent, M., McDonald, M., \& Hunter, R. (2003). Letters to the Editor. Harvard Business Review.

7. Brown, J. S., \& Habel III, J. (2003, July). Letters to the Editor: Does IT Matter? Harvard Business Review, 109-112.

8. Brynjolfsson, E., \& Saunders, A. (2010). Wired for Innovation: How Information Technology is Shaping the Economy. Cambridge, MA: MIT Press.

9. Bulkeley, W. (1996, November 18). When things go wrong. Wall Street Journal, R25.

10. Carnevale, D. (2004, April 9). Cleveland State U. Sues PeopleSoft. Chronicle of Higher Education, 50(31), A34.

11. Carr, N. G. (2003). IT Doesn't Matter. Harvard Business Review, 41-49.

12. Carr, N. G. (2004). Does IT Matter? Information Technology and the Corrosion of Competitive Advantage. Boston: Harvard Business School Press.

13. Cash, J. I., Earl, M. J., \& Morison, R. (2008, November). Teaming Up to Crack Innovation and Enterprise Integration. Harvard Business Review, 86(11), 90-100.

14. Champy, J. (2003, December). Technology doesn't matter -- but only at Harvard. Fast Company, 77.

15. Churchill, G. H. (1991). Marketing Research: Methodological Foundations, 4th ed. New York: Dryden.

16. Dickson, G. W., Leitheiser, R. L., \& Nechis, M. (1984, September). Key Information Systems Issues for the 1980s. MIS Quarterly, 8(3), 135-159.

17. Evans, B. (2003, September 22). It's time to start reaching again. Information Week, 956.

18. Ferranti, M. (2004, September 27). Is IT creativity dead? ComputerWorld.

19. Gilbert, Jr., A. H., Pick, R. A., \& Ward, S. G. (1999). The Role of the CIO: Enduring MIS Issues. Journal of Computer Information Systems, 40(1), 8-16.

20. Gilbert, Jr., A. H., Pick, R. A., \& Ward, S. G. (2003). Effects of Environmental Uncertainty on Perception of Information Systems Issues. Review of Business Information Systems, 7(3), 49-60.

21. Gilbert, Jr., A. H., Pick, R. A., \& Ward, S. G. (2003). Environmental Uncertainty and CIOs' Assessments of Information Systems Issues. Issues in Information Systems, 4(2), 741-747.

22. Giles, M. (2011, October 8-14). IT's Arab Spring. The Economist, 401(8754), pp. Special Report 10-12.

23. Gurbaxani, V. (2003). Letters to the Editor. Harvard Business Review.

24. Hayes, F. (2003, May 19). IT delivers. ComputerWorld.

25. Hinchcliffe, D. (2011, October 2). the "Big Five" IT trends of the next half decade. Retrieved October 3, 2011, from ZDNet: http://www.zdnet.com/blog/hinchcliffe/the-big-five-it-trends-of-the-next-half-decademobile-social-cloud-consumerization-and-big-data/1811

26. Hittleman, J. (2003). Letters to the Editor. Harvard Business Review.

(c) 2012 The Clute Institute http://www.cluteinstitute.com/ 
27. Hopkins, M. S. (2010, Spring). The Four Ways IT is Revolutionizing Innovation. Sloan Management Review, 51(3), 51-56.

28. Hyatt, C. (2003). Letters to the Editor. Harvard Business Review.

29. Jaska, P., Johnson, D. B., Nalla, J., Reddy, N. V., \& Tadisina, R. (2010). Improved Customer Service Using RFID Technology. Review of Business Information Systems, 14(3).

30. Johnson, M. (2004, August 9). Roll your own future. ComputerWorld.

31. Kanaracus, C. (2011, August 12). Epicor sued over alleged ERP project failure. Retrieved 9 26, 2011, from InfoWorld: http://www.infoworld.com/d/the-industry-standard/epicor-sued-over-alleged-erp-projectfailure-169677

32. Kirchoff, B. A. (1994). Entrepreneurship and Dynamic Capitalism.

33. Kirkpatrick, D. (2003, June 9). Stupid-journal alert: why HBR's view of tech is dangerous. Fortune, 147(11), p. 190.

34. Langdon, C. S. (2003). Letters to the Editor. Harvard Business Review.

35. Lee, O.-K. (. (2012). IT-enabled Organizational Transformations to Achieve Business Agility. Review of Business Information Systems, 16(2), 43-52.

36. Lewis, M. S. (2003). Letters to the Editor. Harvard Business Review.

37. Lin, L.-H. (2011, January). Electronic human resource management and organizational innovation: the roles of information technology and virtual organizational structure. International Journal of Human Resource Management, 22(2), 235-257.

38. McFarlan, F. W., \& Nolan, R. L. (2003). Letters to the Editor:. Harvard Business Review.

39. Melville, N., \& Ramirez, R. (2007). Information Technology Innovation Diffusion: An Information Requirements Paradigm. Information Systems Journal, 18, 247-273.

40. Melymuka, K. (2003, July 7). IT does so matter! ComputerWorld.

41. Metcalf, R. M. (2004, June). Why IT Matters. Technology Review, pp. 59-61.

42. Mollenhauer, S. (2003, June 2). Technology still offers strategic value. ComputerWorld.

43. Moschella, D. (2003, June 2). IT mature? Think again. ComputerWorld.

44. Niederman, F., Brancheau, J. C., \& Wetherbe, J. C. (1991, December). Information Systems Management Issues for the 1990s. MIS Quarterly, 15(4), 474-500.

45. Pike, R. L. (2003). Letters to the Editor. Harvard Business Review.

46. Pisello, T. (2003). Letters to the Editor. Harvard Business Review.

47. Rothke, B. (2004, July 1). Implementation is what matters. ComputerWorld.

48. Scott, J. E. (1999). The FoxMeyer Drugs' Bankruptcy: Was it a Failure of ERP. AMCIS Conference Proceedings, 223-225.

49. Skaistis, B. (2003). Letters to the Editor. Harvard Business Review.

50. Stedman, C. (2000a). ERP woes cut Grainger profits. Computerworld(January 7, 2000).

51. Stedman, C. (2000b). IT woes contribute to Hershey sales, profits decline. Computerworld(February 2, 2000).

52. Strassmann, P. A. (2003). Letters to the Editor. Harvard Business Review.

53. Varian, H. (2003, July). Letters to the Editor: Does IT Matter? Harvard Business Review, 112.

54. Wang, P. (2010, March). Chasing the Hottest IT: Effects of Information Technology Fashion on Organizations. MIS Quarterly, 34(a), 63-85.

55. Zwass, V. (2003). Letters to the Editor. Harvard Business Review. 